\title{
Routine Assay for Detection of IgG and IgM Antiglobulins in Seronegative and Seropositive Rheumatoid Arthritis
}

\author{
F. C. HAY, LYNN J. NINEHAM, I. M. ROITT
}

British Medical fournal, 1975, 3, 203-204

\begin{abstract}
Summary
A convenient technique suitable for the routine estimation of IgM and IgG antiglobulins has been devised. The assay involves the binding of antiglobulins (rheumatoid factors) to rabbit immunoglobulin linked to the surface of plastic tubes; the amount of antiglobulin bound is then determined by adding radiolabelled antihuman IgG or IgM. Both antiglobulins were raised in virtually all seropositive rheumatoid arthritics, and 19 out of 22 seronegative patients had raised values for either IgM or IgG rheumatoid factors. The test should prove valuable in diagnosis and the results further emphasize autosensitization to IgG as a dominant immunological characteristic of different forms of rheumatoid arthritis.
\end{abstract}

\section{Introduction}

The most characteristic immunological featurc of rheumatoid arthritis is the presence of serum rheumatoid factors or antiglobulins which react with human or heterologous IgG. Most studies have been made on 19S IgM rheumatoid factors, which are detected in the classical latex and sheep cell agglutination tests, even though the importance of IgG factors in serum has been recognized since $1961,^{1}$ when antiglobulin activity was detected in $11 \mathrm{~S}$ complexes. The synovial fluid of patients with rheumatoid arthritis contains complexes ${ }^{2}$ which are composed entirely of $\mathrm{IgG},{ }^{3}$ some of which, at least, has antiglobulin activity. There is now good evidence that these IgG antiglobulin complexes are important in the pathogenesis of the synovial inflammatory response, ${ }^{4}$ since they have been shown to activate complement and cause a reduction in total haemolytic complement within the synovial fluid. ${ }^{3}$ Furthermore, up to $75 \%$ of the plasma cells in rheumatoid synovial membrane produce IgG antiglobulin. ${ }^{5}$ Moreover, Theofilopoulos et al. ${ }^{6}$ presented evidence which strongly suggests that IgG antiglobulins play a part in the development of rheumatoid vasculitis, while Pope et al. ${ }^{7}$ have shown that the intermediate complexes in the serum of three rheumatoid patients were composed entirely of selfassociated IgG antiglobulins.

We describe here a technique which provides a rapid and simple means of routinely estimating antiglobulins in each immunoglobulin class.

\section{Patients and Methods}

Sera were obtained from 69 patients (20 men and 49 women) with rheumatoid arthritis whose serum reacted positively in the sheep cell agglutination test $(\text { S.C.A.T. })^{8}$ and from 22 S.C.A.T.-negative

\footnotetext{
Department of Immunology, Middlesex Hospital Medical School, London W1P 9PG

F. C. HAY, B.TECH., PH.D., Research Associate

LYNN J. NINEHAM, F.I.M.L.T., Research Technician

I. M. ROITT, D.SC., F.R.C.PATH., Professor of Immunology
}

rheumatoid arthritis patients (three men and 19 women). The duration of disease was from two months to 30 years (mean eight years) for the S.C.A.T.-positive group and from four months to 20 years (mean eight years) for the S.C.A.T.-negative group. All these patients conformed with the American Rheumatism Association criteria for probable, definite, or classical rheumatoid arthritis.

Samples were also obtained from 12 patients with osteoarthritis (four men and eight women), six with traumatic injury (two men and four women), and 13 normal controls working in the immunology laboratory (seven men and six women). All the sera were frozen on the day of collection and kept at $-20^{\circ} \mathrm{C}$ until tested.

Antisera.-Antihuman IgG and IgM were prepared by immunizing rabbits with purified $\mathrm{Fc} \gamma$ or IgM. The anti-IgM was rendered specific by adsorbing with a cyanogen bromide-activated Sepharose- $4 \mathrm{~B}^{\circ}$ immunosorbent of cord serum. The antisera were checked for specificity by immunoeletrophoresis and Ouchterlony immunodiffusion. Purified antibody was prepared by adsorbing the antisera on to cyanogen bromide-activated Sepharose-4B immunosorbents of human IgG or IgM followed by elution of the specific antibody with $0 \cdot 1 \mathrm{M}$ glycine- $\mathrm{HCl}$ buffer, $\mathrm{pH} 2 \cdot 8$. The purified antibodies were then radiolabelled with ${ }^{125} \mathrm{I}$ (Na ${ }^{125} \mathrm{I}$, IMS 4, Radiochemical Centre, Amersham) by a modification of Hunter and Greenwood's method. ${ }^{10}$ Antibody $1 \mathrm{mg}$ in $1 \mathrm{ml}$ phosphate buffered saline (P.B.S.), $0.15 \mathrm{M}$, pH 7.2, was labelled with $500 \mu \mathrm{Ci}^{125} \mathrm{I}$ by adding $60 \mu \mathrm{g}$ chloramine. After two minutes incubation at room temperature $120 \mu \mathrm{g}$ sodium metabisulphite was added to stop the reaction. Free iodine was removed on a Sephadex G25 column. The labelled proteins were stored at $-20^{\circ} \mathrm{C}$

Antiglobulin Assay.-Catt and Tregear ${ }^{11}$ have shown that plastic tubes may be used to bind proteins. We used this principle for our radioassay; $1-\mathrm{ml}$ volumes of rabbit immunoglobulin solution $10 \mathrm{mg} / \mathrm{l}$ in P.B.S. were incubated in polystyrene tubes (LP3, Luckham Ltd., Sussex) for one hour at $37^{\circ} \mathrm{C}$ and then overnight at $4^{\circ} \mathrm{C}$. After three washes with P.B.S. the tubes were incubated at room temperature for two hours with $2 \mathrm{ml}$ of $1 \%$ bovine serum albumin (Armour Pharmaceutical Co. Ltd., Eastbourne) in P.B.S. (B.S.A./P.B.S.) to block any remaining free sites. After three more washes with P.B.S. the tubes were stored at $4^{\circ} \mathrm{C}$. The test sera were heated at $56^{\circ} \mathrm{C}$ for 30 minutes to inactivate complement. Duplicate $50-\mu 1$ samples were placed in the coated plastic tubes together with $450 \mu \mathrm{l}$ of B.S.A./P.B.S. Coated tubes containing $500 \mu \mathrm{l}$ B.S.A./P.B.S. were used as background controls. The tubes were incubated at $37^{\circ} \mathrm{C}$ for one hour and at $4^{\circ} \mathrm{C}$ for 30 minutes. Unbound proteins were then removed by washing three times with cold P.B.S. Human antiglobulins bound to the tubes coated with rabbit immunoglobulin were detected by incubating the tubes with $1 \mu \mathrm{g}$ of purified radiolabelled anti-IgG or IgM in $1 \mathrm{ml}$ B.S.A./P.B.S. at $37^{\circ} \mathrm{C}$ for one hour and at $4^{\circ} \mathrm{C}$ for 30 minutes. Unbound labelled reagent was removed by three washes with cold P.B.S. The tubes were then counted in a gamma-ray spectrometer, the amount of radioactivity bound being a measure of the IgG or IgM antiglobulin in the patient's serum.

\section{Results}

\section{SERUM ANTIGLOBULIN LEVELS}

The IgM and IgG which bound to the tubes was all assumed to be antiglobulin. Though some non-specific binding may occur most, if not all, of the binding activity of IgG antiglobulins has been shown to be present in the Fab fragments. ${ }^{12}$ Using this radioassay we detected raised levels of IgM antiglobulins (rheumatoid factors) in all patients with rheumatoid arthritis who were found to be S.C.A.T. positive (mean \pm S.E. of mean, $1.98 \pm 0.06 \mathrm{mg} / 1$; see fig.). Some of the S.C.A.T.negative group also had raised IgM antiglobulin $(0.87 \pm 0.08 \mathrm{mg} / \mathrm{l})$ and the means of both groups were significantly different from the mean for laboratory staff $(0.60 \pm 0.06 \mathrm{mg} / 1 ; \mathrm{P}<0.01$ by the Wilcoxon test for two samples $\left.{ }^{13}\right)$. Patients with traumatic injury $(0 \cdot 46 \pm 0 \cdot 10$ 
$\mathrm{mg} / \mathrm{l})$ or osteoarthritis $(0.37 \pm 0.06 \mathrm{mg} / \mathrm{l})$ gave even lower values than members of our laboratory staff.

Antiglobulins were also readily detectable in the IgG class (see fig.). Nearly all patients with S.C.A.T.-positive rheumatoid arthritis had raised levels $(0.48 \pm 0.03 \mathrm{mg} / \mathrm{l})$, the mean being significantly different from that of the laboratory staff controls $(0.12 \pm 0.01 \mathrm{mg} / 1 ; \mathrm{P}<0.01)$. IgG antiglobulins were also raised significantly in most patients with S.C.A.T.-negative rheumatoid arthritis $(0.29 \pm 0.05 \mathrm{mg} / 1 ; \mathrm{P} v$. staff $<0.01)$. Only very low concentrations were detected in patients with osteoarthritis $(0.13 \pm 0.01 \mathrm{mg} / \mathrm{l})$ or traumatic injury $(0 \cdot 10 \pm 0.01$ $\mathrm{mg} / \mathrm{l})$.
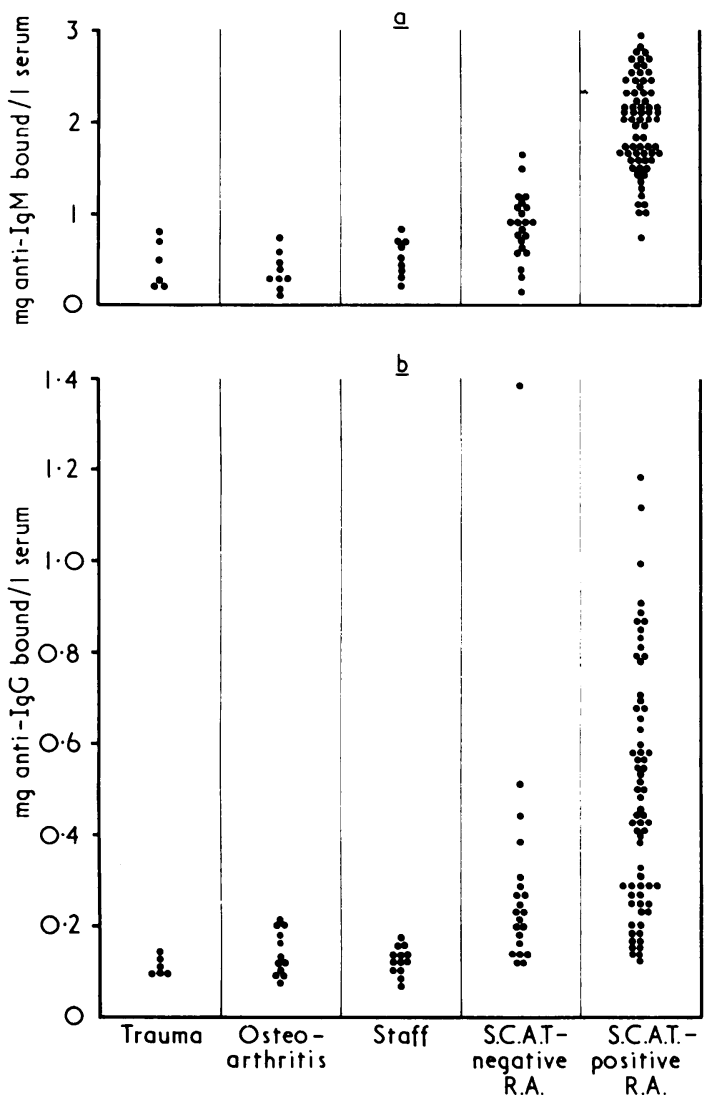

IgM (a) and IgG (b) antiglobulins in the sera of patients with S.C.A.T positive and S.C.A.T.-negative rheumatoid arthritis, traumatic injury, and positive and S.C.A.T.-negative rheur
osteoarthritis and in normal controls.

The raised antiglobulins detected in rheumatoid arthritics by this method could not be ascribed to higher serum immunoglobulins giving greater non-specific binding since essentially similar results were obtained by calculating the amount of antiglobulin per $\mu \mathrm{g}$ of serum IgG and IgM respectively. ${ }^{14}$

\section{Discussion}

Previous methods for detecting IgG antiglobulins have gener- ally involved elution from immunoadsorbents, followed by quantification by single radial immunodiffusion or latex fixation. Cross-linking by benzidine ${ }^{15}$ or glutaraldehyde ${ }^{16}$ or binding to bentonite $^{17}$ or cyanogen bromide-activated agarose ${ }^{18}$ have all been used to produce the immunoadsorbent. Most of these techniques are time consuming and some of the immunoadsorbents, particularly the activated agarose, give unacceptably high non-specific binding of IgG with normal controls. The plastic tube binding technique is relatively free from these problems and may be performed quickly, giving reproducible results in each immunoglobulin class within four hours.

Virtually all the S.C.A.T.-positive sera gave raised IgM and IgG antiglobulin values. Most S.C.A.T.-negative sera also showed raised antiglobulins though the mean was lower than that for the S.C.A.T.-positive group. Altogether $86 \%$ of the S.C.A.T.-negative sera were positive for either IgM or IgG antiglobulins relative to the normal group.

Thus, our test provides a basis for the rapid routine estimation of $\operatorname{IgM}$ and $\operatorname{IgG}$ antiglobulins which should be of diagnostic value in both seronegative and seropositive adult rheumatoid arthritis and Still's disease and should provide quantitative evaluation of research studies, which may allow a more coherent picture of the disease to emerge. Once again the results strongly underline the central immunological feature of rheumatoid arthritis-autosensitization to IgG.

We are grateful to the late Dr. R. Fletcher for the selection of the sera. We thank Mrs. Penny Bardoni for preparation of the manuscript. This work was supported by the Medical Research Council.

\section{References}

${ }^{1}$ Kunkel, H. G., et al., fournal of Clinical Investigation, 1961, 40, 117.

${ }^{2}$ Hannestad, K., Clinical and Experimental Immunology, 1967, 2, 511.

3 Winchester, R. J., Agnello, V., and Kunkel, H. G., Clinical and Experimental Immunology, 1970, 6, 689.

${ }^{4}$ Ziff, M., Progress in Immunology, 1974, vol. 5, p. 37.

5 Munthe, E., and Natvig, J. B., Clinical and Experimental Immunology, $1972,12,55$.

6 Theofilopoulos, A. N., et al., Arthritis and Rheumatism, 1974, 17, 272.

${ }^{7}$ Pope, R. M., et al., Arthritis and Rheumatism, 1975, 18, 97.

${ }^{8}$ Roitt, I. M., and Doniach, D., W.H.O. Manual of Autoimmune Serology. Geneva, W.H.O., 1969.

9 Axén, R., Porath, J., and Ernback, S., Nature, 1967, 214, 1302.

${ }^{10}$ Hunter, W. M., and Greenwood, F. C., Nature, 1962, 194, 495

11 Catt, K., and Tregear, G. W., Science, 1967, 158, 1570.

12 Torrigiani, G., and Roitt, I. M., unpublished observations.

13 Documenta Geigy, Scientific Tables, 6th edn. Macclesfield, Geigy Pharmaceuticals, 1965.

${ }^{14}$ Hay, F. C., et al., in Proceedings of Symposium on Clinical and Immunological Aspects of Still's Disease (Bristol). In press.

15 Torrigiani, G., and Roitt, I. M., Annals of the Rheumatic Diseases, 1967, 26, 334 .

${ }^{16}$ Bianco, N. E., et al., Arthritis and Rheumatism, 1971, 14, 685.

17 Florin-Christensen, A., et al., Annals of the Rheumatic Diseases, 1974, 33, 32.

${ }^{18}$ Bianco, N. E., Dobkin, L. W., and Schur, P. H., Clinical Experimental Immunology, 1974, 17, 91. 